\title{
The response of Petermann Glacier, Greenland, to large calving events, and its future stability in the context of atmospheric and oceanic warming
}

\author{
F.M. NICK, ${ }^{1,2}$ A. LUCKMAN, ${ }^{3}$ A. VIELI, ${ }^{4}$ C.J. VAN DER VEEN, ${ }^{5}$ D. VAN AS, ${ }^{6}$ \\ R.S.W. VAN DE WAL, ${ }^{1}$ F. PATTYN, ${ }^{2}$ A.L. HUBBARD, ${ }^{7}$ D. FLORICIOIU ${ }^{8}$ \\ ${ }^{1}$ Institute for Marine and Atmospheric Research, Utrecht University, Utrecht, The Netherlands \\ ${ }^{2}$ Laboratoire de Glaciologie, Université Libre de Bruxelles, Brussels, Belgium \\ E-mail: fmnick@ulb.ac.be \\ ${ }^{3}$ Department of Geography, College of Science, Swansea University, Swansea, UK \\ ${ }^{4}$ Department of Geography, Durham University, Durham, UK \\ ${ }^{5}$ Department of Geography and Center for Remote Sensing of Ice Sheets, University of Kansas, Lawrence, KS, USA \\ ${ }^{6}$ Geological Survey of Denmark and Greenland, Copenhagen, Denmark \\ ${ }^{7}$ Institute of Geography and Earth Sciences, Aberystwyth University, Aberystwyth, UK \\ ${ }^{8}$ Remote Sensing Technology Institute, German Aerospace Research Center (DLR), Oberpfaffenhofen, Germany
}

\begin{abstract}
This study assesses the impact of a large 2010 calving event on the current and future stability of Petermann Glacier, Greenland, and ascertains the glacier's interaction with different components of the climate and ocean system. We use a numerical ice-flow model that captures the major aspects of the glacier's mass budget, the resistive forces controlling glacier flow, and includes dynamic calving. Satellite observations and model results show that the recent break-off of $25 \%$ of the floating tongue did not result in a significant glacier speed-up due to the low lateral resistance of this relatively wide and thin ice tongue. We demonstrate that seasonal speed-up at Petermann Glacier is mainly driven by meltwater lubrication rather than freeze-up conditions in the fjord. Results also show that sub-shelf ocean melt may have a profound effect on the future stability of Petermann Glacier, emphasizing the urgent need for more observations, and a better understanding of fjord temperature variability and circulation.
\end{abstract}

\section{INTRODUCTION}

Recent studies show that the increased mass loss from the Greenland ice sheet (GIS) is attributed to rapid dynamic changes of fast-flowing outlet glaciers (Rignot and Kanagaratnam, 2006; Joughin and others, 2010a) and enhanced surface melt (Van den Broeke and others, 2009). Beginning in the late 1990s and continuing in the present, many of Greenland's marine-terminating glaciers experienced speedup and retreat of their terminus (Rignot and Kanagaratnam, 2006). These glaciers have been found to respond sensitively and rapidly to atmospheric and oceanic perturbations (Howat and others, 2007; Holland and others, 2008; Murray and others, 2010). Three major outlet glaciers, Jakobshavn Isbræ in West Greenland, and Helheim and Kangerdlugssuaq glaciers in southeast Greenland, almost doubled their flow speed and thinned at rates of tens of metres per year (Joughin and others, 2004, 2008a,b,c; Stearns and Hamilton, 2007). However, in 2006, both Helheim and Kangerdlugssuaq glaciers started to slow down and the terminus readvanced (Murray and others, 2010). An increasing number of studies have shown that the thinning and acceleration take place in all sections along the flowline, although the emerging consensus view is that they are mainly initiated at the glacier front (Howat and others, 2007; Holland and others, 2008; Nick and others, 2009; Murray and others, 2010). Various forcing mechanisms have been proposed, but large uncertainties remain in their relative importance (Vieli and Nick, 2011).

Several recent studies propose that increased discharge from Jakobshavn Isbræ resulted from a reduction in back-stress or a decreasing buttressing effect from the floating ice tongue (Joughin and others, 2004, 2008c; Thomas and others, 2004; Vieli and Nick, 2011). Van der Veen and others (2011) conclude that the observed speed-up is mainly caused by reduced resistance at the lateral margins bounding the fast-moving ice stream, perhaps as a result of cryo-hydrologic warming of subsurface ice or hydraulic weakening due to higher water content at depth. Vieli and Nick (2011) and Joughin and others (in press) suggest that the observed flow acceleration of Jakobshavn Isbræ may be attributed to the joint effect of different processes, which are directly or indirectly related to the loss of the floating ice tongue. In line with these studies, one expects that large calving events and other processes lead to structural weakening or complete collapse of the ice tongue, lower back-stress exerted on the grounded part of the glacier and, through up-glacier propagation of longitudinal stress perturbations, result in increased discharge and glacier thinning.

Calving activities are suggested to be controlled by enhanced crevasse penetration through hydrofracturing by surface meltwater (Van der Veen, 1998; Benn and others, 2007), or by the loss and weakening of sea ice and ice melange in front of the calving terminus (Sohn and others, 1998; Joughin and others, 2008a). Ice melange is believed to exert a small resistive force that prevents the calving front from rotating and breaking off, reducing the calving rate and temporarily stabilizing the terminus (Amundson and others, 2010).

Alternatively, enhanced submarine melt beneath the glacier tongue has been hypothesized to act as a trigger 

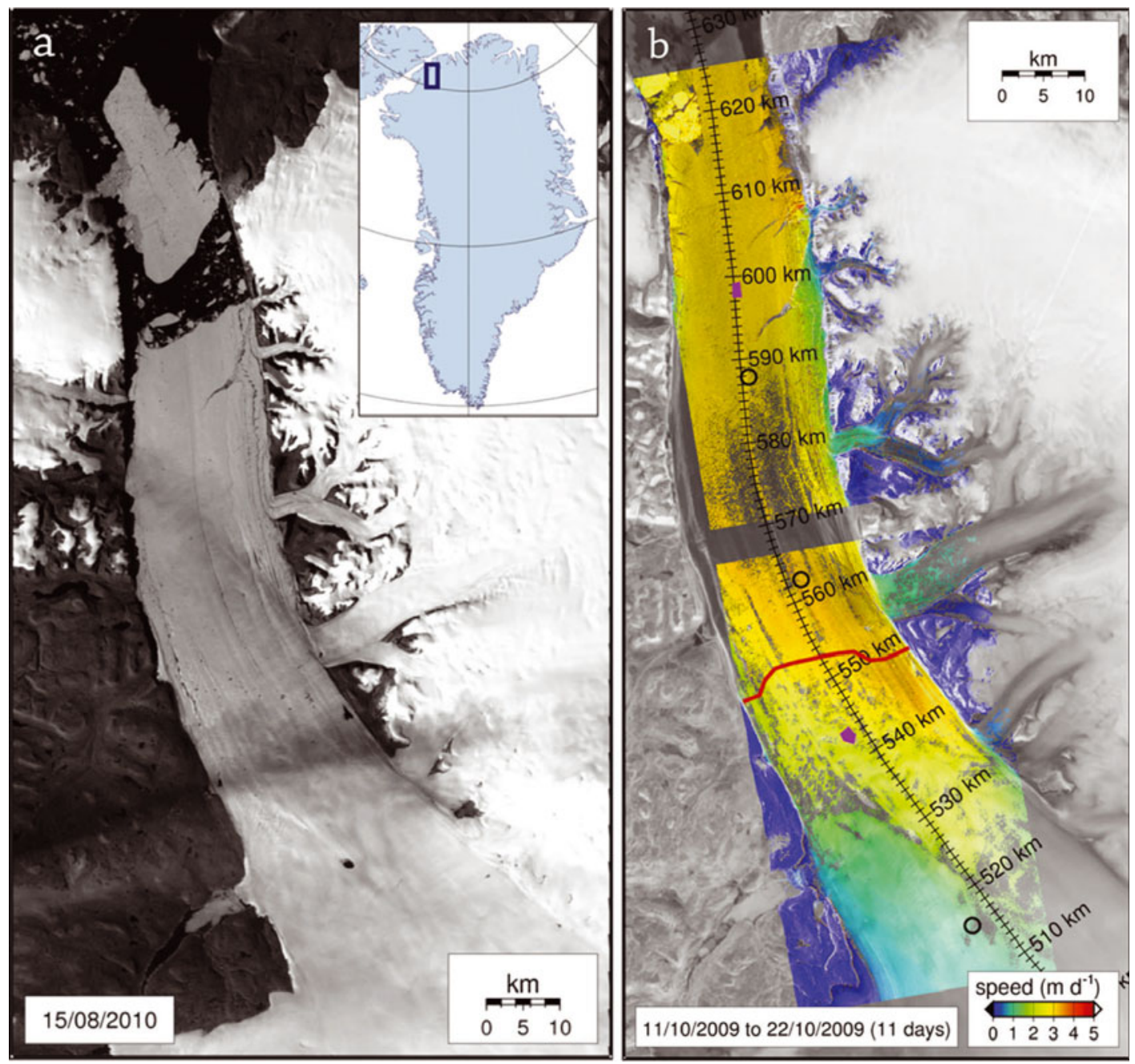

Fig. 1. (a) Panchromatic Landsat 7 image of Petermann Glacier shortly after the 2010 calving event; (b) example of TerraSAR-X feature tracking showing the hinge line (red; Rignot, 1996), the flowline transect (black) and locations (purple) above and below the grounding line selected for observation/model comparison. Black circles illustrate the positions of the recently deployed GPS units. Date format is day/ month/year

for the recent rapid thinning and acceleration of marinebased outlet glaciers and ice streams (Rignot and Jacobs, 2002; Rignot and others, 2008). Retreat and acceleration may be forced directly by increased melting on the underside of the floating ice tongue, especially close to the grounding line (Payne and others, 2004; Holland and others, 2008; Joughin and others, 2010b), which leads to thinning and thereby reduces back-pressure from lateral drag at the sides or ungrounding of pinning points.

Another process that may affect dynamics of outlet glaciers is enhanced sliding caused by surface meltwater reaching the glacier bed and providing additional lubrication at the glacier base (Zwally and others, 2002; Van de Wal and others, 2008; Bartholomew and others, 2010). However, the effect of seasonal melt on ice flow is likely to be more pronounced on slow-moving, land-terminating regions of the ice sheet (Joughin and others, 2008a; Seale and others, 2011) than on fast-moving outlet glaciers which already have relatively low basal traction (Joughin and others, 2008c; Nick and others, 2009).

Currently, the controlling factors for initiating the observed rapid changes of outlet glaciers are still not well understood, but they are critical for predicting the future behaviour of the GIS and its contribution to sea-level rise.
This study is focused on the behaviour of Petermann Glacier, a major outlet glacier in North Greenland. The recent partial disintegration of Petermann Glacier's ice shelf (Fig. 1a) raised concerns regarding its future stability, in particular as its bed below sea level extends far inland $(\sim 100 \mathrm{~km})$ into the GIS allowing ocean water to penetrate deeply inland if the retreat continues. On the other hand, it provides an ideal natural experiment to investigate the dynamic response of the ice sheet to ice-shelf retreat. We first present measurements of ice velocity up- and downstream of the grounding line of Petermann Glacier and use a numerical ice-flow model (Nick and others, 2010) to explore the response of the glacier to this large calving event. Next, we investigate the dynamic sensitivity of this glacier to a range of different forcing mechanisms and assess its stability for several future scenarios. Finally, we use the observed seasonal velocity cycle to assess the potential mechanisms driving seasonal changes in glacier speed.

\section{DYNAMICS AND CALVING OF PETERMANN GLACIER}

Petermann Glacier (Fig. 1a) is one of the largest outlet glaciers in North Greenland, transferring about $13 \mathrm{~km}^{3}$ of ice 
from the interior into the ocean (Rignot and others, 2001) every year. It has the second-longest floating ice shelf among only seven outlet glaciers in Greenland with a permanent floating ice tongue (Rignot, 1997; Rignot and others, 2001; Moon and Joughin, 2008), and flows with an average velocity of just over $1 \mathrm{~km} \mathrm{a}^{-1}$. Unusually for a major Greenland outlet glacier, $80 \%$ of the mass lost from Petermann ice tongue is through submarine ice melt (Rignot and others, 2001), while calving takes place only occasionally, and then occurs as large tabular calving events (Johnson and others, 2011). In August 2010 a large calving event took place along a pre-existing rift, which removed $\sim 25 \%$ of the glacier tongue and formed a tabular iceberg $25 \mathrm{~km}$ long (Falkner and others, 2011). While this behaviour is not unusual for Petermann Glacier, and likely to be part of a natural cycle, the resulting ice front is now at its most retreated position in available satellite records (since 1962), which may reflect a response to climate warming.

\section{VELOCITY}

\subsection{Methods of velocity observations}

Observations of glacier surface velocity are derived from in situ GPS surveys and three satellite sources using feature tracking between repeat-pass pairs of images: (1) Envisat Advanced Synthetic Aperture Radar (ASAR) with a nominal spatial resolution of $30 \mathrm{~m}$, (2) Landsat Enhanced Thematic Mapper (ETM) band 8 (panchromatic) with a nominal spatial resolution of $15 \mathrm{~m}$ and (3) TerraSAR-X (Stripmap mode) with a nominal spatial resolution of $2 \mathrm{~m}$. Each satellite source has its own advantages and disadvantages for this application, but together they provide appropriate spatial and temporal resolution and coverage of velocity fields.

Envisat ASAR provides a noisy retrieval of surface velocity because of its relatively coarse spatial resolution and its long revisit time (35 days), but its all-weather capacity and long archive allows plenty of observations through the modelled time period (2000-10). Landsat ETM is limited to the summer period only, and suffers from the scan-line correction (SLC) problem, which sometimes limits the glacier areas to which feature tracking can be applied. TerraSAR- $X$ is the most valuable source of data for velocity retrievals because of its excellent repeat-pass period (11 days) and very high spatial resolution, but is limited because the only data collected are those requested by investigators.

The feature-tracking method used for ASAR has been adequately described by, for example, Strozzi and others (2002) and Luckman and others (2006) and relies on finding the positions of best match between patches from two images, which are then converted to a surface displacement over the whole glacier. For this study the size of patches depends on the satellite sensor and was chosen to maximize the coverage of velocity measurements while accommodating the maximum flow between images separated by different time periods. The error associated with these measurements depends mainly on the spatial resolution and revisit time, both of which vary according to the sensor and/or the dates of usable archived data. In all cases, however, the error in speed is significantly less than the interannual variability in speed $\left(<40 \mathrm{~m} \mathrm{a}^{-1}\right)$. When comparing surface velocities from image pairs from different sensors, the complicating issue is the time period over which the displacements are measured, and how they sample the flow, which can vary on different timescales in response to tidal, meltwater and other factors. Hence, the data appear to be quite noisy where in fact this variability is an artefact of accumulating a variable flow rate over a variety of time periods.

Figure $1 \mathrm{~b}$ shows an example of a TerraSAR-X velocity field, illustrating the quality of velocity data derived from this very high spatial resolution satellite sensor. Velocity data for three TerraSAR-X image pairs from along the flowline transect (Fig. 1b) are presented in Figure 2a. To illustrate how the velocity changes in time in response to seasonal forcing and the 2010 calving event, data are extracted from two points (purple markers in Fig. 1b), one on the ice shelf and one upstream of the grounding line. In July 2011 we installed three single-frequency GPS units, which transmit their position via the Advanced Research and Global Observation Satellite (ARGOS) every 3 hours. The GPS units are located near the front, and below and above the grounding line (black circles in Fig. 1b). The 3 hourly data are used to calculate velocities at the longer time intervals of the satellite data. The velocities from all datasets including Envisat, Landsat, ten TerraSAR-X pairs and GPS units are presented along with the numerical experiments and are used to constrain the results of the numerical modelling.

\subsection{Results of velocity observations}

The flow speed of Petermann Glacier is highest near the grounding line and more-or-less constant along the floating ice shelf (1100-1400 $\mathrm{m} \mathrm{a}^{-1}$ ) as determined from observations (Fig. 2a). The seasonal variations in flow speed of $\sim 25 \%$ are almost uniform along the whole ice shelf and extend several kilometres upstream of the grounding line. Even in the most densely sampled year (2009), the temporal resolution of our data does not allow a very precise assessment of the start and end of the summer peak in flow, and we can neither detect nor rule out a post-summer slowdown that might be associated with the seasonal evolution of the subglacial drainage system (Howat and others, 2010). However, the summer speed-up is of short duration and seems to be linked to the period of surface melt $(\sim 3$ months). Above the grounding line the velocities are generally $\sim 20 \%$ lower than below, but undergo the same summertime acceleration. The observed velocities since 2006 also show a multi-annual increasing trend on the shelf of $\sim 30 \mathrm{~m} \mathrm{a}^{-2}$, which is shown and discussed in Section 5.4.

After the 2010 calving event, only a very minor acceleration near the terminus is observed (Fig. 2a), with a magnitude well below the seasonal variations. The high spatial resolution TerraSAR-X velocity data (Fig. 1b) reveal only small cross-sectional variations in ice flow, in particular in the lower part of the ice shelf and an abrupt drop in flow speed at their lateral margin, which both suggest limited lateral drag is being provided by the sides.

\section{NUMERICAL FLOW MODEL}

The numerical model simulates evolution of glacier geometry, velocity and stress fields along the main flowline of Petermann Glacier, as described by Nick and others (2010). It balances the driving stress by basal and lateral stresses and longitudinal stress gradients. Model calculations are performed on a moving spatial grid with an average horizontal grid spacing of $400 \mathrm{~m}$, which continuously follows the calving front to overcome numerical issues inherent in 

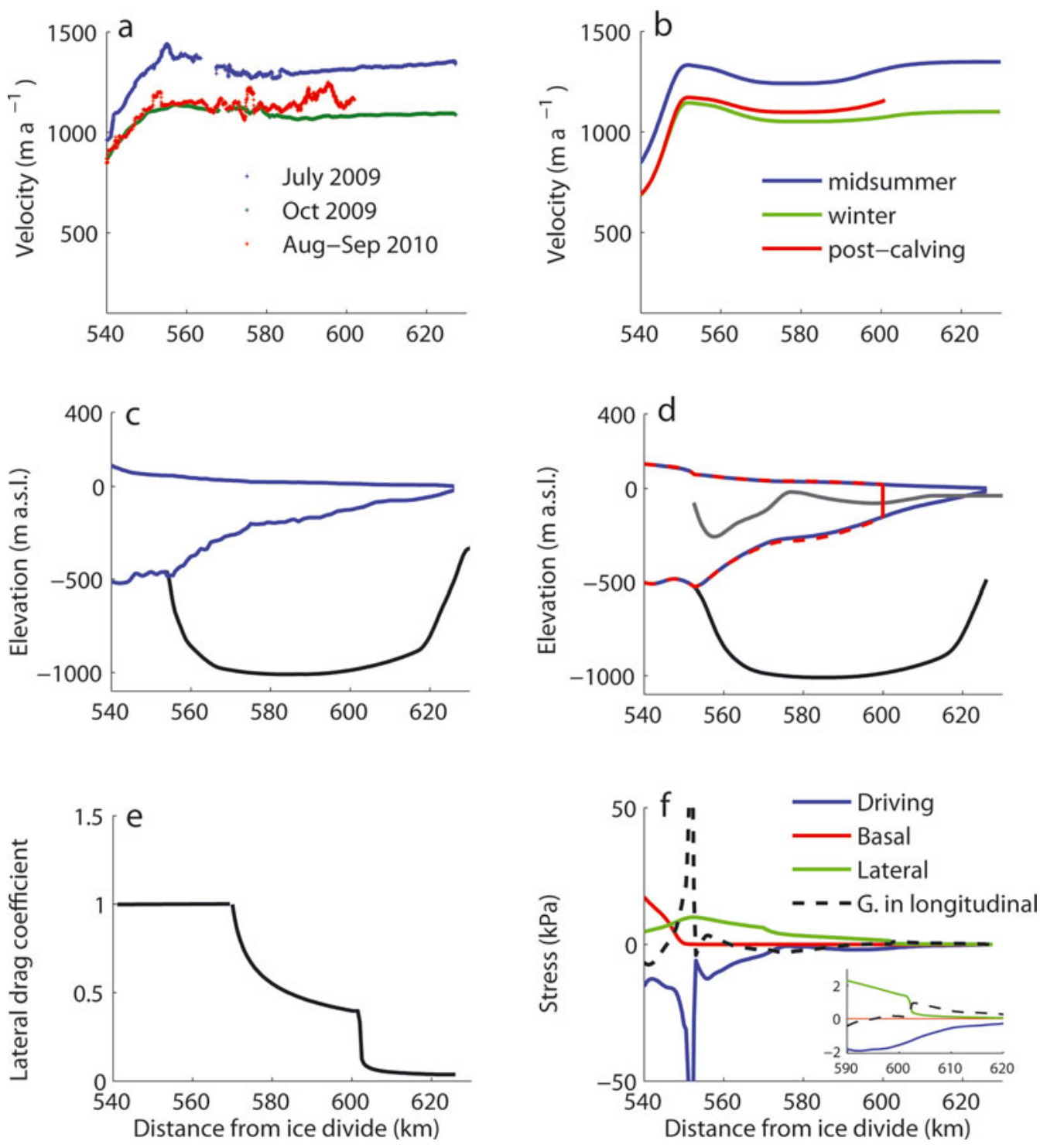

Fig. 2. (a) Satellite-derived surface velocities along the flowline during midsummer (red) and early winter (green) in 2009, and late summer 2010 (blue) shortly after the large calving event. (b) Modelled velocities for seasonal basal lubrication experiment. (c, d) The observed (c) and modelled (d) glacier tongue geometries (blue profiles). The black line is the fjord basal topography. The dashed red profile illustrates the modelled glacier tongue geometry after the 2010 calving event, and the grey line illustrates the prescribed submarine melt rate pattern under the shelf ( $\mathrm{m} \mathrm{a}^{-1}$, ten times exaggerated). (e) Modified lateral drag coefficient along the flowline. (f) Driving stress, basal drag, lateral drag and the gradients in longitudinal stresses along the flowline. The driving stress is plotted as negative to make a clear distinction from the other curves shown. Thus, a negative driving stress acts to drive the ice in the downslope direction; positive values for the other stresses shown correspond to resistance to flow. The inset shows detail near the shelf front.

fixed-grid models (Vieli and Payne, 2005). The model includes a crevasse-depth based calving criterion by which calving occurs when a surface crevasse reaches a depth to which a basal crevasse can penetrate upward (Benn and others, 2007; Nick and others, 2010). While this criterion is not intended to represent the exact physical processes underpinning individual calving events, it does allow for a dynamic response to changes in crevasse fields and seasonal temperature forcing. In doing so, calving losses are linked to ice dynamics and surface meltwater production in a physically plausible way, and the model adequately reproduces observed patterns of seasonal terminus advance and retreat.

For the present simulations the model was improved (Nick and others, 2010) by including a temperature-dependent ice viscosity. In large ice sheets, the flow factor $A$ in Glen's flow law changes by several orders of magnitude between cold and temperate ice zones (Paterson, 1994), which affects the ice viscosity over distances of several hundreds of kilometres (contrast between cold interior and temperate marginal ice). Along the Petermann Glacier flowline, depth-averaged ice temperature varies by $>20^{\circ} \mathrm{C}$, hence temperature-dependent viscosity changes cannot be ignored any more.

A steady-state two-dimensional (2-D) temperature field is calculated along the flowline for the present-day geometry of the glacier constrained by observed horizontal flow speed, using the thermomechanical higher-order model of Pattyn (2002). Boundary conditions are set by near-surface air-temperature observations of the Greenland Climate Network (GC-Net; Steffen and Box, 2001), the surface mass balance derived from the Regional Atmospheric Climate Model (RACMO; Ettema and others, 2010), and a constant geothermal heat flux at the base of $48 \mathrm{~mW} \mathrm{~m}^{-2}$ 
(Shapiro and Ritzwoller, 2004). The flow-rate factor, $A$, is then calculated using the Arrhenius relationship as proposed by Hooke (1981). The obtained temperature field is steady-state and can only be used in an offline way coupled to the one-dimensional flowline model. However, the perturbation experiments we carried out are over very short time-spans of a few decades, which is too short to significantly change the temperature distribution along the flowline, hence the flow-rate factor. Furthermore, the robustness of the temperature field was tested in a series of sensitivity experiments with the 2-D thermomechanical ice-flow model, by varying model parameters and boundary conditions (e.g. geothermal heat flux). While such variations affect the temperature field, but not the spatial pattern of the temperature distribution, their effect is marginal on the vertically averaged flow-rate factor.

The modelled glacier geometry includes the full drainage basin of Petermann Glacier extending from the ice divide to the shelf front. For the upstream basal topography, the digital elevation model (DEM) derived by Bamber and others (2001) is used. For the narrow outlet channel, upstream of the grounding line, we used a smoothed version of the highresolution dataset derived from airborne radio-echo sounding (RES; https://www.cresis.ku.edu/data/greenland), and the surface DEM from the Advanced Spaceborne Thermal Emission and Reflection Radiometer (ASTER) global DEM (GDEM; http://www.gdem.aster.ersdac.or.jp/). The depth of the sea floor in the fjord is not known due to the ice tongue occupying the fjord. We assume a deep fjord under the ice tongue as estimated by Johnson and others (2011) based on several through-ice conductivity-temperature-depth (CTD) measurements. The approximate glacier width is estimated from the surface topography. The surface mass balance along the flowline is derived from RACMO (Ettema and others, 2010).

Model calculations start from a steady-state geometry corresponding to the glacier geometry in 2000 (Section 5.1; Fig. 2c). To include the submarine melt of the floating tongue, a fixed spatial melt pattern is prescribed that is consistent with estimates by Rignot and Steffen (2008). Most of the melt occurs near the grounding line, with the melt rate reaching its maximum of $25 \mathrm{~m} \mathrm{a}^{-1} \sim 10 \mathrm{~km}$ downstream of the grounding line, and decreasing towards the shelf front (Rignot and Steffen, 2008, fig. 1). For the present applications, we keep this pattern constant and fixed to the grounding line position (grey line in Fig. 2c).

\section{MODELLING EXPERIMENTS}

In this section, we present a series of numerical modelling experiments in which we aim to

1. initialize and reproduce the flow of Petermann Glacier before the 2010 calving event,

2. investigate its immediate response to the 2010 calving event,

3. explore its future dynamic response and stability under scenarios of further ice-shelf retreat and/or potential atmospheric or oceanic warming, and

4. determine the forcing mechanisms of the observed large seasonal variations in flow speed.

\subsection{Pre-2010 calving event flow}

In order to reproduce the pre-calving-event flow pattern and geometry, observed in 2000 (Rignot and Steffen, 2008), a very low resistive lateral stress in the lower part of the floating ice tongue is required in the flow model. This finding is strongly supported by the satellite images and the feature-tracking velocity results that reveal only weak (above-water) attachment of the floating ice tongue to its lateral margins and slight cross-flow variations in speed in the frontal region, in particular in the lowest $25 \mathrm{~km}$ that calved away in 2010 (Fig. 1). Such lateral weakening is included in the model by multiplying the ice rheology in the lateral stress term by a lateral drag coefficient. An asymptotic reduction of this lateral drag coefficient by a factor of 1-0.4, first applied for the lower $50 \mathrm{~km}$ from the grounding line and then repeated for the last $25 \mathrm{~km}$ of the shelf (corresponding to the extent of the calving event), allows a successful reproduction of the along-flow geometry and velocity pattern as observed in 2000 (Fig. 2e). Note that this adjustment leads to very low lateral stresses $(<1 \mathrm{kPa}$; Fig. 2f) in the lower $25 \mathrm{~km}$. The corresponding adjusted geometry (Fig. 2d) is used as the initial geometry for the following model experiments.

\subsection{Response to the 2010 calving event}

In the first model experiment, we investigate the response of Petermann Glacier to the 2010 calving event. The large calving event is introduced in the model by simply removing the last $25 \mathrm{~km}$ of the floating tongue. To account for the seasonal background variations in flow speed, we additionally apply a seasonal forcing by regulating the basal lubrication as a linear function of surface runoff. This seasonality is explored further in Section 5.4, and here we focus merely on the effect of the calving event on the glacier flow.

Figure 2 compares the modelled flow against the satellitederived glacier velocity along the flowline. The model emulates well both the observed spatial pattern of velocity and seasonal speed-up for pre-calving-event conditions, suggesting that it is adequately calibrated and performing well (Fig. 2b). The main difference between observations and model output occurs above the grounding line and is explained by the fact that the observations reflect the maximum surface velocity while the model calculates the width-averaged velocity. Where lateral resistance is high, such as above the grounding line, the applied parameterization of lateral drag should indeed result in widthaveraged modelled velocities that are $80 \%$ of those observed along the centre line.

Despite the significant reduction in ice-shelf extent caused by the large calving event of 2010, the model results indicate only a minor speed-up after this event, in agreement with the observations. This insensitivity to shelf retreat is not surprising, as it is a direct consequence of the very low along-flow resistive stresses for the front part of the ice shelf resulting from the limited attachment to the fjord walls, and of the fact that this part of the shelf is thin $(\sim 100 \mathrm{~m})$ and wide $(15 \mathrm{~km})$. The observed and modelled geometry before and after the calving event are illustrated in Figure $2 c$ and $d$, the lateral drag coefficient is shown in Figure $2 \mathrm{e}$, and all relevant stresses along the flowline are summarized in Figure $2 \mathrm{f}$. The driving stress and resistive forces along the shelf are $<10 \mathrm{kPa}$, which is more than an order of magnitude 

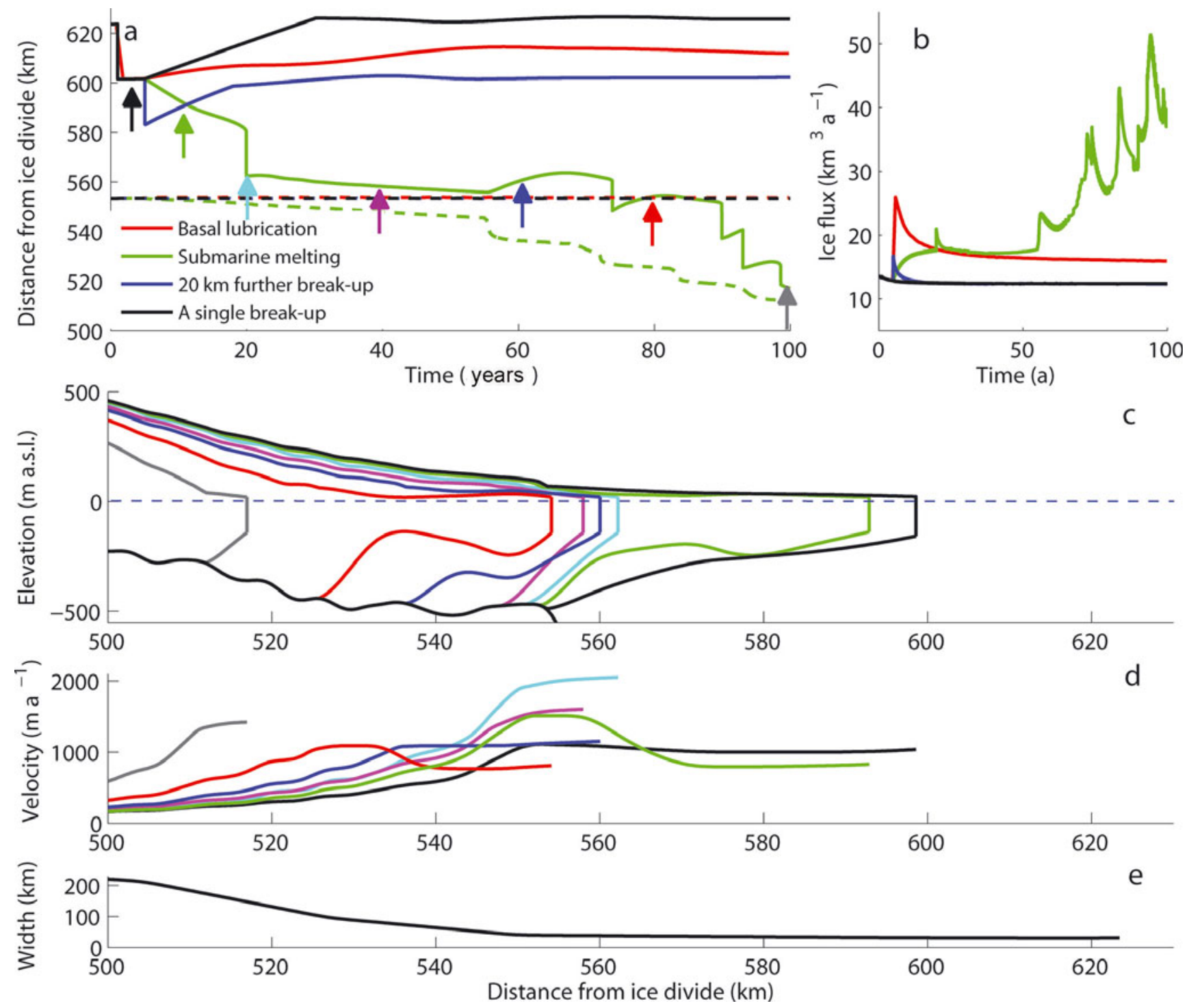

Fig. 3. Response of the shelf front and grounding line to different model perturbations. (a) Grounding line positions (dotted lines) and front position (solid lines). (b) Time evolution of flux at the grounding line for different perturbations (colours match the legend in (a)). The black and blue lines correspond to the shelf retreat by setting the water level (10-70 and 70-130 m, respectively). The red and green lines show the results for the increased basal lubrication and increased submarine melt rate experiments. (c, d) The geometry and velocity profiles for the increased submarine melt rate experiment at different time-steps indicated by arrows in (a). The dark-blue and black profiles display the geometry before and after the large calving event at year 1, respectively. The colour of each profile corresponds to the colour of the arrows. (e) The glacier width along the flowline.

smaller than stresses estimated for the front region of Jakobshavn Isbræ (Van der Veen and others, 2011). Consequently, and in strong contrast to Jakobshavn Isbræ (Vieli and Nick, 2011), the removal of the front part of the shelf did not cause a large change in buttressing forces. The close correspondence between observations and model output implies that the parameterization of geometry and drag coefficients is appropriate, and confirms that for Petermann Glacier, at least in the lower part of the ice shelf, the effect of buttressing is limited.

\subsection{Transient response and future stability}

In the next set of modelling experiments, we impose perturbations corresponding to the processes and forcings discussed in Section 1, and investigate their impact on the dynamics of the glacier. Three main external forcings are considered: shelf retreat, enhanced melt-induced basal lubrication and enhanced submarine melt.
Time evolution of the glacier ice-front position, grounding-line position and ice flux at the grounding line is shown in Figure $3 \mathrm{a}$ and $\mathrm{b}$. At the start of the first experiment (year 1), we remove $25 \mathrm{~km}$ of the shelf by increasing the water level in the surface crevasses from $10 \mathrm{~m}$ to $70 \mathrm{~m}$. This leads to a very slight increase in ice flux and flow, but little change in the grounding line position. Setting back the water level to its original amount of $10 \mathrm{~m}$ after 4 years allows the glacier to readvance and reach its pre-retreat length after $\sim 30$ years. The advance speed of the terminus is close to the flow speed of the glacier, which indicates that calving is suppressed during this readvance. As we lower the water level, the surface crevasses become too shallow to penetrate through the full thickness at the glacier front and fulfil the calving criterion, hence calving is halted until the glacier front thins sufficiently.

In an additional experiment we forced a further shelf retreat of $20 \mathrm{~km}$ after 4 years by setting the water level in 
surface crevasses to a higher value $(130 \mathrm{~m})$. By immediately setting back the water level to its earlier value $(70 \mathrm{~m})$, the glacier starts advancing and forms its previous shelf in $\sim 15$ years. This additional retreat experiment results in a larger increase in velocity and ice discharge than in the first shelfremoval experiment. This enhanced sensitivity to calving can be explained by the greater loss of lateral buttressing as the ice shelf is thicker closer to the grounding line and the lateral drag coefficient is larger. However, this further retreat still does not lead to a grounding line retreat, indicating that calving events of this scale will not be sufficient to destabilize Petermann Glacier. Note that the resulting ice flux anomaly is rather limited and diminishes within a few years.

In order to explore the effect of other perturbations on glacier evolution, we keep the water level in crevasses constant at $70 \mathrm{~m}$ after the first calving event (corresponding to the 2010 event) and apply the other perturbations in year 5 .

In the second experiment we simulate a ten-times increase in the surface melt rate and doubling of the meltseason duration. Assuming that surface melt penetrates to the glacier base, the basal sliding coefficient is reduced by a factor which in our model decays from 1 to 0.1 from $30 \mathrm{~km}$ upstream to the grounding line. Note that in the model the basal sliding coefficient is already inversely proportional to the effective pressure at the bed and thus asymptotically approaches zero near the terminus as the glacier comes close to flotation. This additional prescribed reduction in the basal sliding coefficient causes a net reduction in basal resistance and leads to a flow acceleration and shelf front advance of $\sim 10 \mathrm{~km}$ over 40 years but leaves the grounding line position stationary. Ice flux at the grounding line increases initially from $\sim 12$ to $\sim 26 \mathrm{~km}^{3} \mathrm{a}^{-1}$. The increased ice flux then drops to $50 \%$ of its initial anomaly within a few years and then gradually decreases as the glacier geometry adjusts to the reduced basal resistance. The flow acceleration results in thinning upstream of the lubricated region, which diminishes towards the grounding line where the ice is close to flotation and basal resistance is already very low due to reduced effective pressure at the bed. Consequently, this perturbation results neither in a significant change in glacier thickness at the grounding line nor in grounding line retreat, as similarly demonstrated by Nick and others (2009) from modelling experiments on Helheim Glacier. In an additional experiment (not shown here), decreased lateral drag along the fjord walls in the vicinity of the grounding line causes behaviour similar to that produced by increased basal lubrication.

In the third modelling experiment, we perturb the model by increasing the submarine melt rate underneath the floating shelf by a factor of three, a value prompted by the observation that the amount of heat flux entering Petermann Fjord is enough to accommodate such a melt rate (Johnson and others, 2011). Our experiment shows that increased submarine melt under the shelf results in further retreat of the shelf and grounding line. The higher melt rates underneath the shelf cause it to thin, reducing the lateral resistance. As most melting takes place close to the grounding line, the higher melt rate also steepens the shelf near the grounding line, resulting in a higher gravitational driving force there. This, together with a lower lateral resistance, facilitates acceleration of flow in this section of the glacier, leading to faster ice discharge across the grounding line (Dupont and Alley, 2005; Goldberg and others, 2009). Increased discharge initiates thinning at the grounding line, which propagates upstream and eventually leads to grounding line retreat.

Figure $3 \mathrm{c}$ and d illustrate geometry and velocity profiles of the glacier in different years for the enhanced submarine melt rate experiment, including before and after the 2010 calving event. After applying the perturbation in year 5, there is an initial gradual retreat until year 20, as the shelf front thins and retreats to comply with the calving criterion. The shape of the melt rate profile (Fig. $2 d$ ) means that most of the thinning occurs in front of the grounding line $\sim 570 \mathrm{~km}$ from the ice divide. In year 20 , the shelf becomes too thin to sustain the calving criterion in this region, resulting in a sudden further retreat of $20 \mathrm{~km}$. This new retreat event reduces the resistive stresses as it removes a significant part of the shelf, which is more firmly attached to the fjord walls than the part that calved in 2010. As a result, there is an increase in ice velocity and discharge across the grounding line and subsequent gradual thinning.

In year 55, the shelf starts advancing while the grounding line is still retreating at a slightly faster pace as it passes through a basal deepening ( $\sim 540 \mathrm{~km})$. At this point, the ice discharge from the grounding line rapidly increases (second sudden change) as the grounding line retreats into a basal depression and wider area (Fig. 3e). The higher discharge drains more ice from upstream and transports it to the shelf region, resulting in a thicker and flatter ice shelf and a temporary frontal advance. Note that this additional discharge leads to a remarkably fast surface drawdown above the grounding line (red and orange profiles in Fig. 3c). As the shelf lengthens, submarine melt becomes more effective and again thins the shelf close to the grounding line, causing a large retreat and subsequent increase in ice flux (around year 93).

In summary, the irregular behaviour at the front and grounding line retreat is the consequence of the interplay between several basal depressions, the upstream increase in glacier width and the spatial and temporal fluctuation of the submarine melt. On the other hand, this experiment demonstrates that terminus-position changes may be highly asynchronous to grounding line motion and therefore may not be a valuable diagnostic for the glacier's stability.

Our model result indicates that in the case of three times larger submarine melt rate, there will be an extensive retreat of the shelf front and grounding line $(\sim 40$ and $80 \mathrm{~km}$, respectively), and ice discharge will increase by $\sim 300 \%$ in $<100$ years (Fig. 3a and b). In additional experiments, we examined the sensitivity of the glacier to different multipliers of submarine melt rates (not shown here). Results show the same pattern of grounding-line and shelf-front retreat for lower melt rates, but at different timescales. For example, increasing the submarine melt rate by factors of 2.5 and 2 shows the extensive retreat of the grounding line (similar to what happened in year 50 when applying a factor three, shown in Fig. 3a) significantly later (in years 80 and 185, respectively). Applying even lower factors only results in shelf front retreat and does not trigger the grounding line to retreat $>2 \mathrm{~km}$ (i.e. into the overdeepening part of the bed) after 1000 years.

\subsection{Seasonal dynamics}

The observed seasonal variations in flow speed show a $25 \%$ increase of flow during the brief summer period (Fig. 4a and c). This seasonal pattern in velocity is very similar at the shelf front and above the grounding line, which therefore offers an opportunity to further explore environmental forcing factors. 

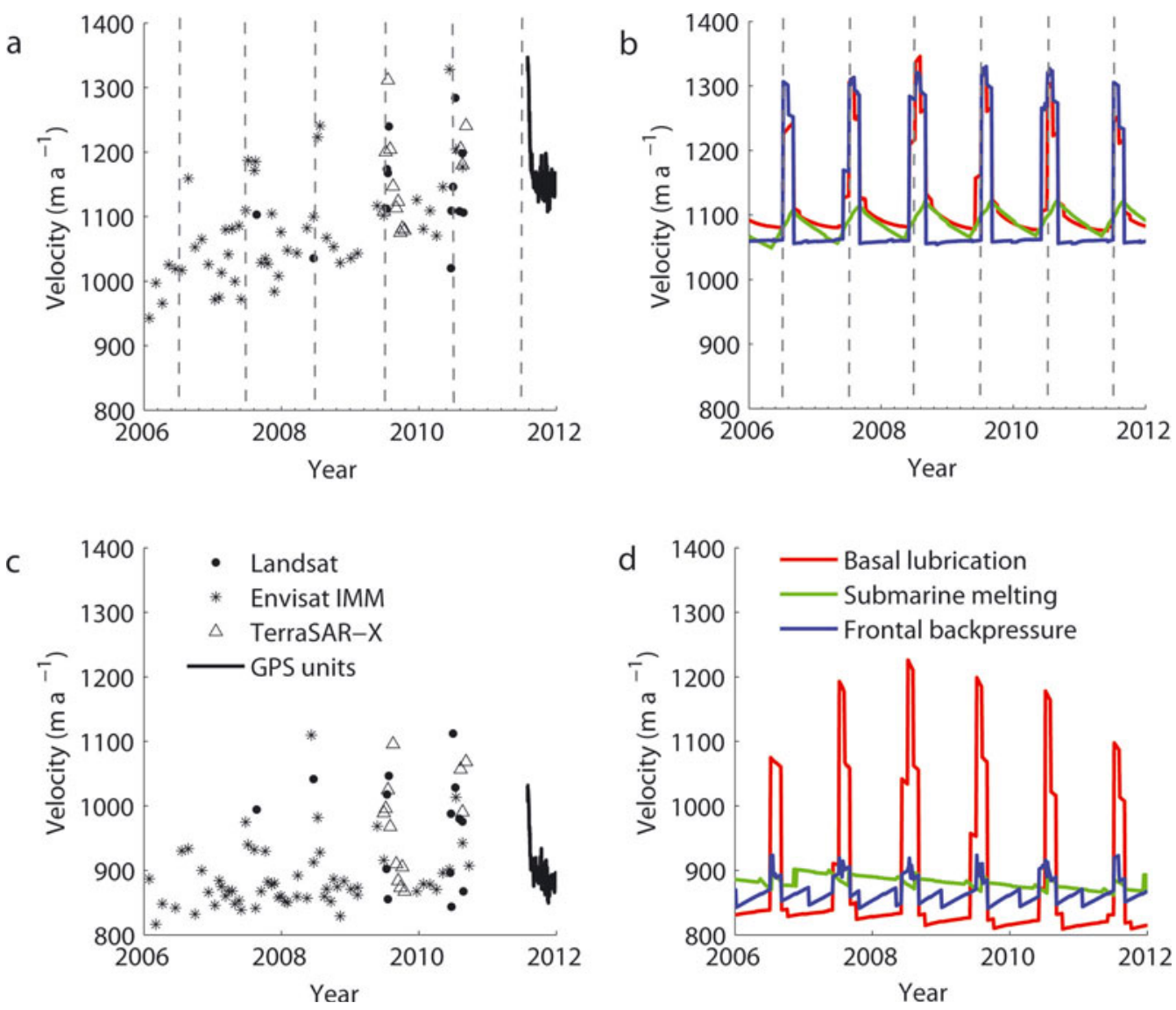

Fig. 4. Observed (a, c) and modelled (b, d) surface ice velocity on the ice shelf (a, b) and above the grounding line (c, d) from 2006 to 2011. Velocities from Envisat, Landsat and TerraSAR-X are shown with stars, circles and triangles, respectively. The black lines show the velocity record of GPS units deployed in July 2011 and estimated for the same locations as the satellite data. Model results from experiments with seasonality in basal lubrication (red), frontal back pressure (blue) and submarine melt rate (green) are illustrated in (b) and (d). The vertical dashed lines indicate midsummer (1 July) for each year.

We compare three plausible seasonal forcings using our model: (1) seasonal variations in submarine melt beneath the shelf driven by the fjord water temperature cycle and enhanced convection from subglacial discharge of summer surface meltwater; (2) seasonal variation in back-stress and lateral drag resulting from concomitant variations in sea ice and ice melange, and; (3) seasonal variation in basal resistance due to surface meltwater availability.

For the first experiment, we keep the submarine melt pattern along the ice shelf constant and fixed to the grounding line, but apply an exaggerated increase (by a factor of ten) in melt rate from April to September each year (Fig. 2d). Such temporal variability in submarine melt produces only small seasonal variations in velocity both at the grounding line and at the ice front, and these are far below the observed magnitudes (Fig. 4b and d). Submarine melt is a gradual process; even a very high melt rate does not result in significant changes in velocity on seasonal timescales. We conclude that enhanced submarine melt is not a potential forcing of the observed seasonality in the surface velocity.

Sea ice in Petermann Fjord may exert a back pressure at the ice front and increases lateral resistance between the fjord walls and floating ice where there is open water in summer. To investigate whether such forcing can explain the observed seasonality in velocity of Petermann Glacier we apply a seasonal reduction in frontal back pressure and side resistance (along the last $20 \mathrm{~km}$ of the shelf, where there is open water in summer). The reduction rate is controlled by the air temperature in the fjord from RACMO simulations (Ettema and others, 2010). Such forcing is able to reproduce the observed variations in velocity near the ice front (Fig. 4a and $b$ ), but the amplitude of the seasonal response experienced above the grounding line is significantly smaller (Fig. 4d), which is not what we observe in the satellite data (Fig. 4c). Thus, this modelling experiment only to a certain extent supports variations in sea-ice or ice melange cover as the governing forcing for the observed seasonal cycle in velocity.

In the last experiment, we modify the basal lubrication by reducing the basal resistance coefficient from 1.0 to $\sim 0.6$, which is a tuned value to produce the observed summer velocities. The value of the resistance coefficient is regulated by the amount of surface meltwater runoff from RACMO simulations. Surface meltwater runoff in the vicinity of the grounding line varies from zero in winter to a maximum of $\sim 0.043 \mathrm{~m}^{3} \mathrm{~m}^{-2} \mathrm{~d}^{-1}$ in summer. Applying a seasonal variation in basal lubrication (Fig. $4 \mathrm{~b}$ and d) causes velocity changes similar to those observed above the grounding line as well as at the ice front. This suggests that processes initiated at or near the grounding line are the dominant control on the observed seasonal velocity variations of Petermann Glacier, but not fully eliminating the influence of variations in lateral resistance and back pressure on the floating ice tongue.

The observed increasing multi-annual trend of flow speed of $\sim 30 \mathrm{~m} \mathrm{a}^{-2}$ between 2006 and 2010 (Fig. 4a) is not reproduced by this model experiment because none of the 
climate parameters used to force the seasonal variation exhibit such a trend. We speculate that this increase is associated with reduced ice-marginal coupling, and can reproduce this in the model by lowering the friction parameter (not shown); a more careful analysis of the 2-D velocity field on the floating tongue is needed to determine the cause of the observed speed-up.

\section{DISCUSSION}

The recent dramatic changes of three major Greenlandic outlet glaciers, Jakobshavn, Helheim and Kangerdlugssuaq glaciers, result from processes that act at the terminus (Howat and others, 2005; Joughin and others, 2008a; Nick and others, 2009; Murray and others, 2010; Vieli and Nick, 2011). Van der Veen and others (2011) suggest that Jakobshavn Isbræ's speed-up is most likely due to weakening of the marginal ice along the last $35 \mathrm{~km}$ of the glacier. Break-up of the floating ice tongue, weakening of the ice in the lateral shear margins, reduction in sea-ice back pressure or enhanced submarine melt at the glacier front all result in loss of resistive stresses, and therefore flow acceleration and further retreat. Our observations and model results for Petermann Glacier contrast with this view. Both observations and modelling show that the detachment of the large part of the floating tongue in August 2010 did not extensively impact the glacier flow and did not increase ice discharge or lead to grounding line retreat. As hypothesized by the satellite observations, our model results confirm that resistive stresses in the terminus region of Petermann Glacier are very small compared to the driving forces higher up at the grounding line. Hence the loss of these resistive stresses as a result of the shelf break-up or weakening of the ice in the lateral shear margins does not significantly affect the glacier flow.

If the recent calving event was an extreme example of natural variability, which is common for calving glaciers and has to a lesser extent been observed for Petermann Glacier before (Falkner and others, 2011), the ice shelf may recover in 30 years according to our model result. Johnson and others (2011) point out that although the recent calving event did not result in flow acceleration and grounding line retreat, the increased ice-free area in the fjord allows the sea surface temperature to rise, which may affect the fjord circulation, prompting a change in submarine melt. They further showed that the net heat flux into the fjord is three times larger than the amount required to cause the submarine melt rate estimated by Rignot and Steffen (2008). In this study we examined the effect of tripling submarine melt rates on glacier dynamics. Our results indicate that an increase in submarine melt can very well lead to complete removal of the floating tongue and a dramatic retreat of the grounding line within the foreseeable future. Note that in this study we assume a constant melt rate pattern along the shelf, as suggested by Rignot and Steffen (2008). For a modified spatial distribution of the submarine melt rate along the shelf of increased melt near or far away from the grounding line, we expect faster or slower retreat of the grounding line respectively (Walker and others, 2008).

Recent studies suggest that enhanced lubrication by seasonal surface runoff has a relatively small influence on fast-flowing outlet glaciers such as Jakobshavn, Helheim and Kangerdlugssuaq glaciers (Joughin and others, 2008b; Nick and others, 2009; Murray and others, 2010). Our model result indicates that on Petermann Glacier seasonal acceleration is controlled by forcings applied to regions at or above the grounding line. Processes such as enhanced basal lubrication due to increased surface runoff are likely controlling the observed seasonal variation in velocity of Petermann Glacier. Whereas changes at the calving front have little impact at the grounding line for the current geometry of Petermann Glacier, variability in the grounded section of the glacier is seen along the entire ice shelf. Hence, even though meltwater is less abundant this far north, and despite the findings for other glaciers (Joughin and others, 2008c; Nick and others, 2009; Schoof 2010), the seasonal acceleration of Petermann Glacier seems mainly controlled by meltwater produced at the surface.

Vieli and Nick (2011) show that a higher submarine melt rate can explain the increased seasonal variation in flow speed of Jakobshavn Isbræ. Increases in submarine melt rate lead to thinning, which triggers retreat when applying the calving criterion. Retreat results in a substantial buttressing reduction and initiates acceleration and further thinning. The case for Petermann Glacier is different; although increased submarine melt results in a large glacier retreat and in strongly enhanced ice flux over a long time period, it cannot explain the seasonality of Petermann Glacier. This is because submarine melt at the shelf front is an order of magnitude smaller than at the grounding line (or on Jakobshavn Isbræ) and, more importantly, thinning at the front may trigger a retreat but it does not result in a substantial loss of buttressing and a subsequent acceleration since the shelf is too thin and resistive stresses are too small.

\section{CONCLUSIONS}

Despite some publicity to the contrary, neither the observations nor the model results point to a significant effect from the loss of $25 \%$ of the floating ice tongue on the flow of Petermann Glacier. The cause lies in the low level of backstress provided by the ice shelf at or near the glacier front. From our numerical modelling, we conclude that marine outlet glaciers with a long and relatively thin ice shelf are not sensitive to changes in their terminus region.

From combined velocity observations and model results, we conclude that the seasonal variations in the velocity of Petermann Glacier are mainly controlled by surface melt and consequently enhanced basal lubrication, and to a lesser extent by frontal back pressure caused by ice melange or sea ice.

Our results further show a dominating influence of subshelf ocean melt on future glacier stability. This emphasizes the urgent need for more observations of fjord temperatures and heat circulation.

\section{ACKNOWLEDGEMENTS}

Financial support was provided by the Netherlands Organization of Scientific Research (NWO) in the framework of the Netherlands Polar Programme (NPP) and contributing to the Knowledge for Climate (KvK) programme in the Netherlands, and by the ice2sea programme within the European Union 7th Framework Programme, grant No. 226375 (ice2sea contribution No. 067). TerraSAR-X data were provided by DLR under project HYD0178, and Envisat data by the European Space Agency under project AOCRY.2676. Landsat data were downloaded from the US Geological Survey (USGS) Global Visualization Viewer. 


\section{REFERENCES}

Amundson JM, Fahnestock M, Truffer M, Brown J, Lüthi MP and Motyka RJ (2010) Ice mélange dynamics and implications for terminus stability, Jakobshavn Isbræ, Greenland. J. Geophys. Res., 115(F1), F01005 (doi: 10.1029/2009JF001405)

Bamber JL, Layberry RL and Gogineni SP (2001) A new ice thickness and bed data set for the Greenland ice sheet. 1 . Measurement, data reduction, and errors. J. Geophys. Res., 106(D24), $33773-33780$

Bartholomew I, Nienow P, Mair D, Hubbard A, King MA and Sole A (2010) Seasonal evolution of subglacial drainage and acceleration in a Greenland outlet glacier. Nature Geosci., 3(6), 408-411 (doi: 10.1038/ngeo863)

Benn DI, Warren CW and Mottram RH (2007) Calving processes and the dynamics of calving glaciers. Earth-Sci. Rev., 82(3-4), 143-179 (doi: 10.1016/j.earscirev.2007.02.002)

Dupont TK and Alley RB (2005) Assessment of the importance of ice-shelf buttressing to ice-sheet flow. Geophys. Res. Lett., 32(4), L04503 (doi: 10.1029/2004GL022024)

Ettema J, Van den Broeke MR, Van Meijgaard E, Van de Berg WJ, Box JE and Steffen K (2010) Climate of the Greenland ice sheet using a high-resolution climate model: Part 1: evaluation. Cryos. Discuss., 4(2), 561-602 (doi: 10.5194/tcd-4-561-2010)

Falkner KK and 11 others (2011) Context for the recent massive Petermann Glacier calving event. Eos, 92(14), 117 (doi: 10.1029/2011EO140001)

Goldberg DN, Holland DM and Schoof CG (2009) Grounding line movement and ice shelf buttressing in marine ice sheets. J. Geophys. Res., 114(F4), F04026 (doi: 10.1029/2008JF001227)

Holland DM, Thomas RH, de Young B, Ribergaard MH and Lyberth B (2008) Acceleration of Jakobshavn Isbræ triggered by warm subsurface ocean waters. Nature Geosci., 1(10), 659-664 (doi: 10.1038/ngeo316)

Hooke RLeB (1981) Flow law for polycrystalline ice in glaciers: comparison of theoretical predictions, laboratory data, and field measurements. Rev. Geophys. Space Phys., 19(4), 664-672

Howat IM, Joughin I, Tulaczyk S and Gogineni S (2005) Rapid retreat and acceleration of Helheim Glacier, east Greenland. Geophys. Res. Lett., 32(22), L22502 (doi: 10.1029/2005GL024737)

Howat IM, Joughin IR and Scambos TA (2007) Rapid changes in ice discharge from Greenland outlet glaciers. Science, 315(5818), 1559-1561

Howat IM, Box JE, Ahn Y, Herrington A and McFadden EM (2010) Seasonal variability in the dynamics of marine-terminating outlet glaciers in Greenland. J. Glaciol., 56(198), 601-613 (doi: 10.3189/002214310793146232)

Johnson HL, Münchow A, Falkner KK and Melling H (2011) Ocean circulation and properties in Petermann Fjord, Greenland. J. Geophys. Res., 116(C1), C01003 (doi: 10.1029/2010JC006519)

Joughin I, Abdalati W and Fahnestock MA (2004) Large fluctuations in speed on Greenland's Jakobshavn Isbræ glacier. Nature, 432(7017), 608-610 (doi: 10.1038/nature03130)

Joughin I and 7 others (2008a) Continued evolution of Jakobshavn Isbræ following its rapid speedup. J. Geophys. Res., 113(F4), F04006 (doi: 10.1029/2008JF001023)

Joughin I and 8 others (2008b) Ice-front variation and tidewater behavior on Helheim and Kangerdlugssuaq Glaciers, Greenland. J. Geophys. Res., 113(F1), F01004 (doi: 10.1029/2007JF000837)

Joughin I, Das SB, King MA, Smith BE, Howat IM and Moon T (2008c) Seasonal speedup along the western flank of the Greenland Ice Sheet. Science, 320(5877), 781-783 (doi: 10.1126/science.1153288)

Joughin I, Smith BE, Howat IM, Scambos T and Moon T (2010a) Greenland flow variability from ice-sheet-wide velocity mapping. J. Glaciol., 56(197), 415-430

Joughin I, Smith BE, Holland DM (2010b) Sensitivity of 21st century sea level to ocean-induced thinning of Pine Island Glacier, Antarctica. Geophys. Res. Lett., 37(20), L20502 (doi: 10.1029/ 2010GL044819)
Luckman A, Murray T, de Lange R and Hanna E (2006) Rapid and synchronous ice-dynamic changes in East Greenland. Geophys. Res. Lett., 33(3), L03503 (doi: 10.1029/2005GL025428)

Moon T and Joughin I (2008) Changes in ice front position on Greenland's outlet glaciers from 1992 to 2007. J. Geophys. Res., 113(F2), F02022 (doi: 10.1029/2007JF000927)

Murray T and 10 others (2010) Ocean regulation hypothesis for glacier dynamics in southeast Greenland and implications for ice sheet mass changes. J. Geophys. Res., 115(F3), F03026 (doi: 10.1029/2009JF001522)

Nick FM, Vieli A, Howat IM and Joughin I (2009) Large-scale changes in Greenland outlet glacier dynamics triggered at the terminus. Nature Geosci., 2(2), 110-114 (doi: 10.1038/ngeo394)

Nick FM, Van der Veen CJ, Vieli A and Benn DI (2010) A physically based calving model applied to marine outlet glaciers and implications for the glacier dynamics. J. Glaciol., 56(199), 781-794 (doi: 10.3189/002214310794457344)

Paterson WSB (1994) The physics of glaciers, 3rd edn. Elsevier, Oxford

Pattyn F (2002) Transient glacier response with a higher-order numerical ice-flow model. J. Glaciol., 48(162), 467-477 (doi: 10.3189/172756502781831278)

Payne AJ, Vieli A, Shepherd A, Wingham DJ and Rignot E (2004) Recent dramatic thinning of largest West Antarctic ice stream triggered by oceans. Geophys. Res. Lett., 31(23), L23401 (doi: 10.1029/2004GL021284)

Rignot E (1997) Ice discharge from north and northeast Greenland as observed from ERS interferometry. In Proceedings of the 3rd ERS Symposium on Space at the Service of our Environment, 14-21 March, 1997, Florence, Italy. European Space Agency, Noordwijk, 815-818 (ESA Special Publication 414)

Rignot E and Jacobs SS (2002) Rapid bottom melting widespread near Antarctic ice sheet grounding lines. Science, 296(5575), 2020-2023

Rignot E and Kanagaratnam P (2006) Changes in the velocity structure of the Greenland Ice Sheet. Science, 311(5673), 986-990 (doi: 10.1126/science.1121381)

Rignot E and Steffen K (2008) Channelized bottom melting and stability of floating ice shelves. Geophys. Res. Lett., 35(2), L02503 (doi: 10.1029/ 2007GL031765)

Rignot E, Gogineni S, Joughin I and Krabill W (2001) Contribution to the glaciology of northern Greenland from satellite radar interferometry. J. Geophys. Res., 106(D24), 34 007-34 019

Rignot E, Box JE, Burgess E and Hanna E (2008) Mass balance of the Greenland ice sheet from 1958 to 2007. Geophys. Res. Lett., 35(20), L20502 (doi: 10.1029/2008GL035417)

Schoof C (2010) Ice-sheet acceleration driven by melt supply variability. Nature, 468(7325), 803-806 (doi: 10.1038/ nature09618)

Seale A, Christoffersen P, Mugford RI and O'Leary M (2011) Ocean forcing of the Greenland Ice Sheet: calving fronts and patterns of retreat identified by automatic satellite monitoring of eastern outlet glaciers. J. Geophys. Res., 116(F3), F03013 (doi: 10.1029/ 2010JF001847)

Shapiro NM and Ritzwoller MH (2004) Inferring surface heat flux distribution guided by a global seismic model: particular application to Antarctica. Earth Planet. Sci. Lett., 223(1-2), 213-224

Sohn HG, Jezek KC and Van der Veen CJ (1998) Jakobshavn Glacier, West Greenland: 30 years of spaceborne observations. Geophys. Res. Lett., 25(14), 2699-2702

Stearns LA and Hamilton GS (2007) Rapid volume loss from two East Greenland outlet glaciers quantified using repeat stereo satellite imagery. Geophys. Res. Lett., 34(5), L05503 (doi: 10.1029/2006GL028982)

Steffen K and Box J (2001) Surface climatology of the Greenland ice sheet: Greenland Climate Network 1995-1999. J. Geophys. Res., 106(D24), 33 951-33964

Strozzi T, Luckman A, Murray T, Wegmuller $U$ and Werner $\mathrm{CL}$ (2002) Glacier motion estimation using satellite-radar 
offset-tracking procedures. IEEE Trans. Geosci. Remote Sens., 40(11), 2834-2391 (doi: 10.1109/TGRS.2002.805079)

Thomas RH, Rignot EJ, Kanagaratnam K, Krabill WB and Casassa C (2004) Force-perturbation analysis of Pine Island Glacier, Antarctica, suggests cause for recent acceleration. Ann. Glaciol., 39, 133-138 (doi: 10.3189/172756404781814429)

Van de Wal RSW and 6 others (2008) Large and rapid melt-induced velocity changes in the ablation zone of the Greenland Ice Sheet. Science, 321(5885), 111-113 (doi: 10.1126/science.1158540)

Van den Broeke $M$ and 8 others (2009) Partitioning recent Greenland mass loss. Science, 326(5955), 984-986 (doi: 10.1126/science.1178176)

Van der Veen CJ (1998) Fracture mechanics approach to penetration of surface crevasses on glaciers. Cold Reg. Sci. Technol., 27(1), 31-47

Van der Veen CJ, Plummer JC and Stearns LA (2011) Controls on the recent speed-up of Jakobshavn Isbræ, West
Greenland. J. Glaciol., 57(204), 770-782 (doi: 10.3189/ 002214311797409776)

Vieli A and Nick FM (2011) Understanding and modelling rapid dynamic changes of tidewater outlet glaciers: issues and implications. Surv. Geophys., 32(4-5), 437-458 (doi: 10.1007/ s10712-011-9132-4)

Vieli A and Payne AJ (2005) Assessing the ability of numerical ice sheet models to simulate grounding line migration. J. Geophys. Res., 110(F1), F01003 (doi: 10.1029/2004JF000202)

Walker RT, Dupont TK, Parizek BR and Alley RB (2008) Effects of basal-melting distribution on the retreat of ice-shelf grounding lines. Geophys. Res. Lett., 35(17), L17503 (doi: 10.1029/ 2008GL034947)

Zwally, HJ., Abdalati W, Herring T, Larson K, Saba J and Steffen K (2002) Surface melt-induced acceleration of Greenland Ice Sheet flow. Science, 297(5579), 218-222 (doi: 10.1126/ science.1072708)

MS received 21 November 2011 and accepted in revised form 20 January 2012 